\title{
Human Capital, Income Inequality and Economic Variables: A Panel Data Estimation from a Region in Indonesia*
}

\author{
Indra SUHENDRA ${ }^{1}$, Navik ISTIKOMAH ${ }^{2}$, Rah Adi Fahmi GINANJAR ${ }^{3}$, Cep Jandi ANWAR ${ }^{4}$
}

Received: August 01, 2020 Revised: September 06, 2020 Accepted: September 10, 2020

\begin{abstract}
This paper examines how human capital and other economic variables, such as private investment, economic growth, government investment, inflation, and unemployment influence inequality in Indonesia's provinces. We apply panel data model with fixed effect estimation for the data of 34 provinces from the period 2013 to 2019. We develop a new index for human capital using the education index approach. The results show that human capital has a negative and significant effect on income inequality. An increase in human capital is related to an increase in knowledge and competence due to the longer average school year and expectations of the school year. Human capital has increased the possibility of a person being accepted into the job market and earning a higher income; hence, it lowers income inequality. We also find that inflation leads to a higher gap of income distribution. A further implication of this situation is that the rise in inflation causes an increase in low-income people, and as a consequence, makes their lives worse off. This paper will be beneficial for policy-makers for whom human capital, which is measured using an education index, is an important factor that significantly affects income inequality, in addition to other economic factors.
\end{abstract}

Keywords: Human Capital, Income Inequality, Investment, Economic Growth, Panel Data

JEL Classification Code: O15, 040, 042, J60

\section{Introduction}

A discussion regarding income inequality in a region or a country is related to the level of a country's development

\footnotetext{
*Acknowledgements:

The authors would like to acknowledge financial support from University of Sultan Ageng Tirtayasa for this research (Grant Number: T/300/UN 43.5./PT. 01.01/2019).

${ }^{1}$ First Author and Corresponding Author. Assistant Professor, Department of Economics and Development Studies, Universitas Sultan Ageng Tirtayasa, Banten, Indonesia [Postal Address: Jalan Raya Jakarta Km.4 Pakupatan Serang City, Banten, 42118, Indonesia] Email: indras_23@untirta.ac.id

${ }^{2}$ Assistant Professor, Economics Education Department, Universitas

Pendidikan Indonesia, Bandung, Indonesia.

Email: navik.istikomah@upi.ac.id

${ }^{3}$ Assistant Professor, Department of Economics and Development Studies, Universitas Sultan Ageng Tirtayasa, Banten, Indonesia. Email: rah.adi@untirta.ac.id

${ }^{4}$ Assistant Professor, Department of Economics and Development Studies, Universitas Sultan Ageng Tirtayasa, Banten, Indonesia. Email: cepjandianwar@untirta.ac.id

() Copyright: The Author(s)

This is an Open Access article distributed under the terms of the Creative Commons Attribution Non-Commercial License (https://creativecommons.org/licenses/by-nc/4.0/) which permits unrestricted non-commercial use, distribution, and reproduction in any medium, provided the original work is properly cited.
}

that provides an equal benefit to society in that region. This benefit can be interpreted as revenue that is received by the society equally. Levin and Bigsten (2000) and Afonso et al. (2010) argued that successful development, not only achieves high economic growth, but impacts on economic growth, which creates greater income for society and is distributed more equally. Therefore, successful development can be measured as an increase in economic growth that produces distribution of income equally. Branson (1989) agrees and maintains that an increase in economic growth produces a more equal distribution of income in society.

Todaro and Smith (2012) state that income equality is the distribution of functional income. Todaro argued that total national income would be distributed equally to the production factor. Thus, national income will be distributed according to the production function (wage for labour, rent for land owners and profit for capital). However, if the achievement of economic growth does not produce income distribution equally, it potentially generates two significant problems: first, the occurrence of an income gaps among people, and second an increase in poverty. Deininger and Olinto (1999) explain that those problems create dilemmas for governments, i.e., governments prefer economic growth 
or a reduction in income inequality. Currently, some economists appear to favour a reduction in income inequality over an increase in economic growth.

In Indonesia, economic growth over the last five years (2015-2019) showed an average of 5.03\%. However, that achievement has been unsuccessful in achieving the equal distribution of income. This failure can be observed in the average of Indonesia's Gini index indicator in the last five years, which was 0.4. According to Jun et al. (2011), a Gini index of 0.4 marks the lower threshold level of unequal income distribution. Thus, we conclude that income inequality is occurring in Indonesia.

Prior studies show that human capital is the main factor to influence income inequality. According to Lee and Lee (2018) and Jun et al. (2011), an increase in human capital, due to more widespread education, contributes to reducing income inequality significantly. In this paper, we investigate the relationship between human capital and income inequality. We measure human capital as the average school year for the population of Indonesia. We use a data panel for 34 provinces in Indonesia, with annual data from the period 2013 to 2019.

Many factors influence income inequality and previous studies show that human capital is still one of the main factors that can significantly affect income inequality, in addition to other macroeconomic factors. Lee and Lee (2018) and Jun et al. (2011) explain that human capital sourced from a more equitable education contributed significantly to reducing inequality. This paper aims to understand the relationship between human capital and income inequality, in particular, how human capital, which is measured by average school year, has an effect on income inequality in Indonesia, by means of using panel data for the provincial level from the period 2013 to 2019.

A summary of prior empirical studies reveal that results are inconclusive regarding the relationship between human capital and income inequality. The effect of human capital on income inequality can be positive or negative. Nevertheless, it is still essential that the role of human capital on income inequality be investigated, as human capital is the main priority of every country as regards development.

This paper differs from existing studies because we employ the newest education index developed by the United Nations Development Programme (UNDP) as a substitute for human capital. Education index is measured by combining two distinct components: pupil's average school year and school year that is expected for pupils. Each component has a weight of $50 \%$. Most prior studies use education index that measures adult literacy rates (weighing two-thirds) and a combination of rough registration ratios from primary, secondary and tertiary schools (weighted a-third). Thus, there is a difference in the size of human capital applied in this study with the size of human capital used in previous studies, such as average school year (Becker \& Chiswick, 1966; Afonso et al., 2010; Jaumotte et al., 2013; Lustig et al., 2013; Autor, 2014), education level variance data (De Gregorio \& Lee, 2002), average school year and the education Gini index (Chani et al., 2014; Lee \& Lee, 2018), as well as the weighted education index (Jun et al., 2011).

\section{Literature Review}

The relationship between human capital and income inequality can be seen in the empirical studies conducted by Becker and Chiswick (1966). They state that human capital determines income inequality. In their study, human capital is measured using distribution of education and average school year, while education inequality is measured by school variances. Their result explained that the supply and demand of educated people influence income inequality. They claim that there is a positive relationship between education inequality and income inequality. Moreover, average school year might influence income inequality positively or negatively. It depends on the development of education return. A further study by De Gregorio and Lee (2002) explains that education inequality is determined by level of education and return of education. An increase in level of education results in higher income inequality.

Empirical research that examines the relationship between human capital and income inequality, such as the research completed by Checchi (2001), Afonso et al. (2010), Jun et al. (2011), Lustig et al. (2013), Jaumotte et al. (2013), Autor (2014), as well as Lee and Lee (2018), claims that human capital has a negative influence on income inequality. Checchi (2001) contends that educational achievement has a strong negative impact on income inequality. Afonso et al. (2010) state that the level of education could reduce the occurrence of income inequality. The same statement is made by Jun et al. (2011), who assert that human capital and education costs have a significant and negative effect on income inequality. Lustig et al. (2013) explain that the decrease in labor income inequality was attributed to higher education.

Jaumotte et al. (2013) show that income inequality has a relationship with average school year, where income inequality tends to increase as people graduating from secondary or higher education increases. According to Autor (2014), in recent decades, developed countries have shown that an increase in higher education and highly skilled people contributes significantly to an increase in income inequality. This statement is supported by Lee and Lee (2018) who found that education inequality and level of education have a positive effect on income inequality. However, Climent and Domenech (2014) show evidence of a weak correlation 
between a change in human capital and income inequality. This suggests that a reduction in human capital does not automatically decrease income inequality. In their study, they applied the Gini index level of education as a proxy for human capital, while income inequality is measured as the Gini index of income.

\section{Data and Methodology}

\subsection{Data}

This paper uses panel data for 34 provinces in Indonesia with annual data from the period 2013 to 2019. Income inequality is proxied by a Gini index that shows the level of income distribution of people in each province in Indonesia - the index is between 0 and 1. Human capital is measured by an education index developed by the UNDP. This index reflects the level of knowledge of people in a province - the index is between 0 and 1 . The formula for education index to measure human capital follows the NDP (HDI Report, 2010) UNDP (2010):

$$
\begin{aligned}
& E I=(M S Y I+E Y S I) / 2 \\
& M S Y I=M S Y / 15 \\
& E Y S I=E Y S / 18
\end{aligned}
$$

where EI is educational index, MSYI is mean years of schooling index and EYSI is expected years of schooling index. Mean years of schooling (MYS) is calculated by the average number of years of education of people aged 25 years and above, based on the level of education obtained by the population - it is converted into school years based on the duration of each level of education attended, while expected years of schooling (EYS) is a calculation of the number of years pupils expected to attend school or university. The data employed is the sum of the ratio for each level of education; primary, intermediate, post-secondary and higher education. The index is calculated from the participation rate of each level with the assumption that every child has the same pattern. Mean years of schooling and expected years of schooling are obtained from the Central Statistics Agency.

Private and government investments are the total amount of private investment (FDI and DDI) and the provincial government's investment in the capital goods infrastructure each year in million US\$. Economic growth is the rate of annual growth of PDRB for each province in Indonesia. It is measured based on the constant 2010 price. Inflation is calculated as the percentage change of the consumer price index over the corresponding period in each province in Indonesia. Unemployment is defined as the percentage of those who are unemployed out of the total labor force for each province in Indonesia. The data for income inequality, inflation, economic growth, and unemployment have been obtained from the Central Statistics Agency, whereas the private investment and government investment data have been obtained from the Investment Coordinating Board.

\subsection{Econometrics Methodology}

The methodology to analyze the effect human capital relations and other economic variables have on income inequality is a multiple regression equation using panel data, which combine time series and cross-sectional data. To determine the best panel estimation for equations (4), and whether it is appropriate to use common effect, fixed effect or random effect models, we conduct Chow and Hausman tests. We also perform classical assumption tests to make our model unbiased.

In our model, we add various factors that influence income inequality significantly. Blejer and Guerrero (1990) use government investment, economic growth, unemployment, inflation, and exchange rates. Their conclusions indicate that government investment and economic growth have a negative effect on income inequality, while unemployment, inflation, and exchange rates have a positive influence on income inequality. Ahn (1997) and Deyshappriya (2017) establish that an increase in unemployment and inflation results in an increase in income inequality, whereas an increase in economic growth reduces income inequality. Jha (1998) found that economic growth and public investment had a negative effect on income inequality. Karbasi and Mojarad (2008) ascertained that public investment related to infrastructure reduce income inequality significantly. Through their research, Levin and Bigsten (2000); Jun et al. (2011); and Bouincha and Karim (2018) posit a negative relationship between economic growth and income. Additionally, Glomm and Ravikumar (1992) conclude that an increase in private investment and government investment reduce income inequality. However, certain empirical results show that the role of inflation on income inequality is inconclusive, (Sieron, 2017; Siami-Namini \& Hudson, 2019; Law \& Soon, 2020; Kartaev et al., 2020).

Therefore, in this study, we combine macroeconomic variables that have a significant effect on income inequality to illustrate how income inequality is affected by those variables. Our model is:

$$
\begin{aligned}
I D_{i t}+\alpha_{i} & +\beta_{1} H C_{i t}+\beta_{2} \ln P I_{i t}+\beta_{3} G R T_{i t}+\beta_{4} \ln G I_{i t}+\beta_{5} I N F_{i t} \\
& +\beta_{6} U N E M P_{i t}+\varepsilon_{i t}
\end{aligned}
$$

In equation (4), $i=1,2, \ldots, N$ for provinces cross-sections, $t=1,2, \ldots, T$ for time series, ID explains income inequality (Gini index), HC shows human capital index, PI is the realisation of private investment, GRT is economic growth, 
GI is government investment, INF is inflation, UNEMP is unemployment, while $\alpha i$ is sectoral special effect.

\section{Empirical Results}

\subsection{Descriptive Statistics}

Table 1 shows the descriptive statistics of variables in this study. As regards income inequality over a 7-year period, the lowest is 0.2690 and the highest 0.4590 . This indicates that Bangka Belitung is the province with the lowest income inequality (0.2690), whereas Papua is the province with the highest income inequality $(0.4590)$.

Furthermore, the data for human capital are extremely interesting. They reveal that the minimum education index is 0.457 for Papua province and the maximum education index is 0.7450 in the province of Yogyakarta. The data indicate that there are differences in the level of knowledge and education inequality of the inter-provincial population in Indonesia. Yogyakarta is known as a city that promotes education, while Papua, located at the end of the eastern of Indonesia, has limited opportunity for society to attend school, from primary education to high education.

Generally, the average inflation in all provinces in Indonesia appears relatively low, approximately $4.6 \%$. This inflation rate is within the limit of the inflation target set by the government of Indonesia, which is $3-4 \%$ with a deviation of $1 \%$. However, it is interesting that the maximum inflation is $11.91 \%$ in the province of North Kalimantan. This high inflation relates to the location of the province, which is located next to Malaysia, and the status of the province as the newest province in Indonesia. As a new province, the distribution of goods and services are limited in North Kalimantan and some of the basic needs of the people are fulfilled by Malaysia. Currently, as regards North Kalimantan's economic development, the province's basic needs can be fulfilled by the distribution of logistics from neighbouring provinces.

Concerning economic growth, even though the average economic growth for all provinces in Indonesia is relatively high at $5.38 \%$, there is significant gap however, between the highest and lowest level of economic growth. Maximum economic growth is $21.76 \%$ (province of West Nusa Tenggara), whereas minimum economic growth of $15.72 \%$ is observed in Papua province. Lowest economic growth is related to the economic structure of Papua province, which depends on natural resources. Thus, when the production of natural resources slows down, it will have a significant effect on economic growth. Related to private investment (FDI and DDI), as well as government investment, the realisation of investment is relatively diverse among provinces. This is due to the attractiveness of investment and the ability of the fiscal and financial budget of each province.

\subsection{Result of Chow and Hausman Tests}

Table 2 shows Chow and Hausman tests to determine the best panel estimation for our model. Based on the Chow test, the value of the Prob. Cross-section of Chi Square $<$ Alpha $(5 \%)$ or $0.0000<0.05$. The Hausman test indicates that the value of the Prob. Cross-section Random $<$ Alpha $(5 \%)$ or $0.0038<0.05$. Based on those tests, it can be concluded that the best estimation for panel regression for our model is the fixed effect model (FEM).

\subsection{Result of Classical Assumption and Normality Tests}

Classic assumption and normality tests were performed to determine the validity of the data. The classical assumption test consists of multicollinearity, heteroscedasticity, and autocorrelation tests. Table 3 presents a correlation matrix to detect whether or not there is a multicollinearity problem in relation to our data. Based on the result of the multicollinearity test using a correlation matrix, as seen in Table 3, the correlation among independent variables is less than 0.80 . It can be concluded that there is no linear relationship between independent variables. Thus, there is no multicollinearity problem in our data.

Table 1: Descriptive Statistic

\begin{tabular}{|l|c|c|c|c|}
\hline Variable & Mean & Std Dev. & Min. & Max. \\
\hline ID & 0.3627 & 0.0396 & 0.2690 & 0.4590 \\
\hline HC & 0.6259 & 0.0489 & 0.4570 & 0.7450 \\
\hline PI & 6.4026 & 1.4333 & 2.0800 & 9.1400 \\
\hline GRT & 5.3812 & 2.5281 & -15.720 & 21.760 \\
\hline GI & 6.7883 & 9.8200 & 0.0000 & 0.9143 \\
\hline INF & 4.6127 & 2.6554 & -0.0500 & 11.910 \\
\hline
\end{tabular}


Table 2: Result of Chow and Hausman Tests

\begin{tabular}{|c|c|c|c|}
\hline No. & Testing & Value & Conclusion \\
\hline \multirow{3}{*}{1.} & Chow test & & \\
\hline & Cross-section chi-square & 77.693 & \multirow{2}{*}{ fixed effect model (FEM) } \\
\hline & Prob. & 0,0000 & \\
\hline \multirow{3}{*}{2.} & Hausman test & & \\
\hline & Cross-section random & 19.194 & \multirow{2}{*}{ fixed effect model (FEM) } \\
\hline & Prob. & 0.0038 & \\
\hline
\end{tabular}

Table 3: The Result of Multicollinearity Test

\begin{tabular}{|l|c|c|c|c|c|c|}
\hline & HC & PI & GI & GRT & INF & UNEMP \\
\hline HC & 1 & 0.0045 & 0.1735 & -0.0509 & -0.2444 & 0.3008 \\
\hline PI & 0.0045 & 1 & 0.6036 & -0.0603 & -0.1442 & 0.2329 \\
\hline GRT & -0.0509 & -0.0603 & -0.1182 & 1 & 0.1069 & -0.1341 \\
\hline GI & 0.1735 & 0.6036 & 1 & -0.1182 & -0.2620 & 0.3733 \\
\hline INF & -0.2444 & -0.1442 & -0.2620 & 0.1069 & 1 & 0.0527 \\
\hline UNEMP & 0.3008 & 0.2329 & 0.3733 & -0.1341 & 0.0527 & 1 \\
\hline
\end{tabular}

Table 4: The Result of Heteroscedasticity, Autocorrelation and Normality Tests

\begin{tabular}{|c|c|c|c|}
\hline Num. & Testing & Value & Conclusion \\
\hline \multirow{5}{*}{1.} & \multicolumn{3}{|l|}{ Heteroscedasticity (White test) } \\
\hline & n-observed & 238 & \multirow{4}{*}{$\begin{array}{c}x_{\text {count }}^{2}<x_{26 ; 0.05}^{2} \\
\text { no heteroscedasticity }\end{array}$} \\
\hline & r-squared & 0.1465 & \\
\hline & Chi Square count & 34.8862 & \\
\hline & Chi Square table $(26 ; 0.05)$ & 38.8851 & \\
\hline \multirow{6}{*}{2.} & Autocorrelation (Durbin-Wat & & \\
\hline & Durbin-Watson count & 1.9480 & \multirow{5}{*}{$\begin{array}{c}\mathrm{D}_{\mathrm{U}}<1.9480<4-\mathrm{D}_{\mathrm{U}} \\
\text { no autocorrelation }\end{array}$} \\
\hline & Nilai $D_{L}$ & 1.7437 & \\
\hline & Nilai $D_{U}$ & 1.8306 & \\
\hline & Nilai $4-D_{u}$ & 2.1694 & \\
\hline & Nilai 4-D & 2.2563 & \\
\hline \multirow{3}{*}{3.} & Normality (Jarque-Bera test) & & \\
\hline & Jarque-Bera & 1.4778 & \multirow{2}{*}{ normally distributed } \\
\hline & Prob. & 0.4776 & \\
\hline
\end{tabular}

Table 4 shows the results of the white test to detect the existence of the heteroscedasticity problem, the DurbinWatson test to detect the existence of the autocorrelation problem, and the Jarque-Bera test to examine whether or not the residual of our data is distributed normally. We conclude that the data in this study are free from heteroskedasticity as well as autocorrelation problems and that the residual data have a normal distribution.

\subsection{Result of Fixed Effect Model}

Table 5 reveals the result of panel data estimation with the fixed effect model. It shows that human capital has a negative and significant effect on income inequality, inflation and government investment have a positive and significant effect on income inequality, and that private investment has a positive, but insignificant effect on income inequality. 
Table 5: Fixed Effect Estimation

\begin{tabular}{|l|c|c|c|}
\hline Variable & Estimate & t-Statistics & Prob. \\
\hline $\mathrm{HC}$ & -0.5537 & -6.6117 & $0.0000^{* * *}$ \\
\hline $\mathrm{PI}$ & 0.0013 & 0.9269 & 0.3551 \\
\hline $\mathrm{GRT}$ & -0.0006 & -1.2909 & 0.1982 \\
\hline $\mathrm{GI}$ & 0.0036 & 2.0604 & $0.0407^{* *}$ \\
\hline $\mathrm{INF}$ & 0.0011 & 2.5365 & $0.0120^{* *}$ \\
\hline UNEMP & -0.0024 & -3.1587 & $0.0018^{* * *}$ \\
\hline Constant & 0.6868 & 12.418 & $0.0000^{* * *}$ \\
\hline $\mathrm{R}^{2}$ & 0.9537 & & \\
\hline Adj. $\mathrm{R}^{2}$ & 0.9446 & & \\
\hline F-statistic & & 104.7592 & 0.0000 \\
\hline Durbin-Watson stat & 1.948046 & & \\
\hline
\end{tabular}

Notes :

1. The dependent variable is income inequality.

2. The symbols ${ }^{*},{ }^{* *},{ }^{* * *}$ denote statistical significance at the $10 \%$, $5 \%$ and $1 \%$.

While human capital and unemployment have a negative and significant effect on income inequality, economic growth has a negative, but insignificant effect on income inequality. We can also see the result of the coefficient of determination (R-Square) and coefficient of determination after adjusting (adjusted R-Square), where the R-square value is 0.9537 and ADJ. R-squared is 0.9446 . This suggests that all independent variables are able to describe variations in income inequality by $95.37 \%$ or $94.46 \%$ after adjusting, while the remainder of $4.63 \%$ or $5.54 \%$ after adjusting, is explained by variations in other variables that are not included in the model. Furthermore, the F-statistic is 104.7592 and significant at $1 \%$. This result indicates that all independent variables have a significant effect on the dependent variables.

\section{Discussion}

We can see from the results in Table 5 that the negative influence of human capital on income inequality is significant at $5 \%$ with a coefficient of -0.5537 . This result strengthens previous studies, which show the negative relationship between human capital and income inequality, such as Checchi (2001), Afonso et al. (2010), Jun et al. (2011), Lustig et al. (2013), Jaumotte et al. (2013), Autor (2014), besides Lee and Lee (2018). This result implies that an increase in human capital results in a reduction in income inequality. The higher human capital reflected by higher education indicates that there is a greater probability of being accepted into the job market and earning an income (Le et al., 2019). An increase in human capital is related to an increase in knowledge and competence due to the longer average school year and expectations of the school year. In short, in the case of Indonesia, human capital has increased the possibility of a person being accepted into the job market and earning a higher income; hence, it lowers income inequality.
It should be noted that higher human capital means the longer the average school year obtained during his/her lifetime. Therefore, for example, a person with a university education has a greater chance of being employed in the formal or industrial sectors jobs in these sectors that require excellent skills that help a person to earn a better income. In contrast, a person with low average school year, generally has less knowledge and a low level of education. As a consequence, he/she will find it challenging to obtain a good job in the formal and industrial sectors due to limited human capital. Finally, that person commonly secures informal sector employment that is associated with a low income. When high and low human capital enters the job market, there will be an income difference between both groups. This income gap encourages greater income inequality. In short, an increase in human capital by increasing average school year causes a reduction in knowledge inequality, thus, a reduction income inequality.

Another finding in this study relates to private investment. From the result, it can be seen that private investment has a positive effect on income inequality, but the effect is insignificant. This suggests that an increase (decrease) in private investment does not significantly increase (decrease) income inequality. This finding is inconsistent with the results from Glomm and Ravikumar (1992), Karbasi and Mojarad (2008) and Le and Nguyen (2020) who state that an increase in private investment, both foreign direct investment and domestic direct investment, is expected to reduce income inequality. Hence, private investment encourages new employment opportunities and subsequently results in people earning greater incomes; as a result, income inequality decreases. The reason why private investment in Indonesia has a different effect on income equality is because the spread of private investment is unequal among provinces. This is proven by our data that show the average for private investment across provinces in Indonesia is disproportionate. For example, the average private investment in six provinces on Java Island is US\$5,839.01 million (approximately $55.94 \%$ of total private investment). The second highest private investment is in Borneo with five provinces. Here, the amount of private investment is US\$1,681.70 million (16.11\%). Moreover, this private investment is about a quarter of the private investment in Java. However, private investment in Maluku Island, North Maluku, Papua and West Papua is roughly US\$572.60 million $(5.49 \%)$ or approximately $9 \%$ of the private investment in Java. The inequality relating to private investment creates different job vacancies in each province. Job vacancies in Java Island are greater than in other islands; thus, it encourages different income that can be earned by the people in each region. 
Next, we move to the effect of economic growth on income inequality. The result reveals that the effect of economic growth on income inequality is negative, but insignificant at the $5 \%$ level of confidence. This result denotes that higher economic growth does not automatically decrease income inequality. According to economics theory, an increase in economic growth causes a decline in income inequality, while higher economic growth reflects an increase in value added in economic sectors, then lowers income inequality. Furthermore, greater economic growth creates increasing activity in the economic sectors; subsequently absorbing labour. This, therefore, results in more equal income. Nevertheless, in the case of the provinces in Indonesia, economic growth does not influence society much. In certain provinces, high economic growth is attributable to an increase in capital-intensive manufacturing industry. This sector requires fewer workers and hence, does not have a significant impact on a province's income. This condition is the reason why economic growth has a negative effect on income inequality, although the effect is not significant.

From the data, we can see that the average economic growth during the period 2013 to 2018 in Sulawesi Island was $7.17 \%$, which did not have a significant impact on decreasing income inequality in that region. The average of the Gini index for the same period in Sulawesi Island was 0.3901. This ratio is greater than the average Gini index associated with Sumatra and Borneo, which is 4.64 and $4.72 \%$, although the economic growth in both islands is smaller than the average economic growth in Sulawesi. This finding is not in line with prior studies by Blejer and Guerrero (1990), Ahn (1997), Jha (1998), Levin and Bigsten (2000), Afonso et al. (2010), and Salim et al. (2020) who state that an increase in economic growth results in a decline in income inequality.

The effect of government investment on economic growth is positive and significant at $5 \%$. This result is not in agreement with the expected hypothesis that greater government investment reduces income inequality. An increase in government investment, both local and central government investment, mostly in the form of physical goods such as buildings, machines, computers for general administration, as well as public infrastructure (road construction, irrigation, ports, communication networks, railways) do not reduce income inequality. This finding is clearly inconsistent with the conclusions drawn by Blejer and Guerrero (1990), Glomm and Ravikumar (1992), Jha (1998) and Afonso et al. (2010) who maintain that government investment is the main factor in lowering income inequality. Our finding indicates that local government investment in infrastructure does not provide benefits to increase public economic activity and also does not have an effect on many residents with respect to production activities, which potentially increase income (Olilingo \& Putra, 2020). Consequently, government investment does not reduce income inequality. Afonso et al. (2010) state that government investment succeeds in lowering income inequality if the benefit of government spending creates an increase in economic activity resulting in better incomes for communities. Another reason for this particular effect of economic growth on income equality is that the development of public infrastructures financed by government investment is relatively small and limited so that it is less effective in increasing public income, especially for people on low incomes.

The influence of inflation on income inequality is positive and significant at $1 \%$. This result implies that an increase (decrease) in inflation leads to an (increase) decrease in income inequality. This result strengthens the previous studies undertaken by Blejer and Guerrero (1990), Ahn (1997), Sieron (2017) and Law and Soon (2020). Ahn (1997) claims that inflation causes a decline in real money since the real value of money is smaller than the previous period. Conversely, those who have wealth in the form of fixed assets or non-liquid assets benefit as a result of inflation. Therefore, inflation creates a wider gap in income. Sieron (2017) asserts that inflation lowers the real value of social benefits for society because the real value of social benefits drops with an increase in price; then it reduces the real income of social benefit receivers. Generally, social benefit receivers are low-income people. Therefore, inflation contributes to increasing inequality for low-income communities. A further implication of this situation is that the rise in inflation causes an increase in low-income people, and as a consequence, makes their lives worse (Law \& Soon, 2020). A contrasting result is shown by Siami-Namini and Hudson (2019) and Kartaev et al. (2020). According to Siami-Namini and Hudson (2019), inflation reductions do not help to reduce income inequality, whereas the empirical findings by Kartaev et al. (2020) assert that, when inflation rises, then income inequality reduces to reach a minimum level, although income inequality increases in the following periods.

The last control variable in our model is unemployment. Unemployment has a negative effect on income inequality and it is significant at $1 \%$. This result is not in accordance with our expectation because the effect of unemployment rate on income inequality should be positive. This finding is not in line with the results of Blejer and Guerrero (1990), Ahn (1997), Afonso et al. (2010) and Kousar et al. (2020). Ahn (1997) states that the level of unemployment has a considerable effect on income inequality regarding people on low-incomes as well as high-income populations. This is because more unemployment results in more people not having an income. An increase in unemployment due to job loss leads to a reduction in people's income, with low- 
skilled workers feeling the effect first because they are the first affected by their loss of employment. Our result in this study contradicts the aforementioned phenomena, where an increase in unemployment lowers income inequality. The data of the average Gini index and the average unemployment rate across the provinces in Indonesia during the period 2013 to 2019 show a reverse relationship between those variables, such as provinces in Sumatera and Kalimantan in addition to the eastern islands of Indonesia (Maluku, North Maluku, Papua and West Papua). In those provinces, when the level of unemployment is high, the Gini index is low. In contrast, in the provinces of Bali, NTB, NTT and Sulawesi, when the level of unemployment is high, the Gini index is high.

\section{Conclusion and Recommendation}

This study found that human capital had a negative and significant effect on income inequality. This finding is consistent and supports previous studies that duration of school year as an indicator of knowledge encourages a decrease in income inequality. Furthermore, the average length of school and expected length of school as a measurement of human capital have an important role in reducing income inequality. However, regarding macroeconomic variables, the effect of private investment, government investment and unemployment on income inequality, our findings show that those variables are insignificant in relation to reducing income inequality. However, only inflation has a significant and negative effect on income inequality.

The results of this study have yielded a few recommendations both for local and central government. The first is that the government needs to increase the budget to develop human capital. Currently, based on regulation in Indonesia, $20 \%$ of the Indonesia's national budget is allocated to education. Our findings strengthen that regulation or if possible, recommend that a larger budget be allocated to education. The second recommendation is that the government should finance an extensive range of human capital enhancement program in order to increase average school years, so that human capital can be improved. Therefore, it is recommended that the financing of infrastructure should be reduced and transferred to the human capital improvement program. This suggestion is relevant to other research findings that government investment related to financing infrastructure has no significant effect on reducing income inequality. The last suggestion is related to inflation and attempts to maintain price stability. Thus, each province in Indonesia should achieve the inflation target as a reduction in inflation reduces income inequality.

\section{References}

Afonso, A., Schuknecht, L., \& Tanzi, V. (2010). Income distribution determinants and public spending efficiency. The Journal of Economic Inequality, 8(3), 367-389.

Ahn, K. (1997). Trends in and Determinants of Income Distribution in Korea. Journal of Economic Development, 22(2).

Autor, D. H. (2014). Skills, Education, and the Rise of Earnings Inequality. Science, 344(6186), 843-51.

Becker, G. S., \& Chiswick, B. R. (1966). Education and the Distribution of Earnings Among the "Other 99 percent". American Economic Review, 56(1/2), 358-69.

Blejer, M. I., \& Guerrero, I. (1990). The Impact of Macroeconomic Policies on Income Distribution: An Empirical Study of the Philippines. The Review of Economics and Statistics, 72(3), 414-423.

Bouincha, M., \& Karim, M. (2018). Income Inequality and Economic Growth: An Analysis Using a Panel Data. International Journal of Economics and Finance; 10(5), 242-253.

Chani, M. I., Pervaiz, Z., Jan, S. A., \& Chaudhary, A. R. (2014). Human Capital Inequality and Income Inequaity: testing for Causality. Quality \& Quantity, 48(1), 149-156.

Checchi, D. (2001). Education, Inequality and Income Inequality. LSE STICERD Research Paper No. 52.

Climent, A. C., \& R. Domenech. (2014). Human Capital and Income Inequality: Some Facts and Some Puzzles. BBVA Research Working Paper, 12-28.

De Gregorio, J. D., \& Lee, J. W. (2002). Education and Income Inequality: New Evidence from Cross-Country Data. Review of Income and Wealth, 48(3), 395-416

Deininger, K., \& Olinto, P. (1999). Asset distribution, inequality, and growth. Washington, DC: The World Bank.

Deyshappriya, N. P. R. (2017). Impact of Macroeconomic Factors on Income Inequality and Income Distribution in Asian Countries. ADBI Working Paper No. 696. Tokyo, Japan.

Glomm, G., \& Ravikumar, B. (1992). Public Versus Private Investment in Human Capital: Endogenous Growth and Income Inequality. Journal of Political Economy, 100(4), 818-895.

United Nations Development Programme. (2010). Human Development Report 2010. Londdon, UK: Palgrave Macmillan.

Jaumotte, F., Lall, S., \& Papageorgiou, C. (2013). Rising Income Inequality: Technology, or Trade and Financial Globalization?. IMF Economic Review, 61(2), 271-309.

Jha, S. K. (1998). Fiscal Policy, Income Distribution, and Growth. EDRC Report Series 67. Asian Development Bank.

Jun, Y., Zong-Kui, Y., \& Peng-Fei, S. (2011). Income Distribution, Human Capital and Environmental Quality: Empirical Study in China. Energy Procedia, 5, 1689-1696. 
Karbasi, A., \& Mojarad, S. (2008). Impact of Public Investment on Iran Rural Income Inequality. American-Eurasian Journal Agriculture and Environment Science, 2, 131-134.

Kartaev, P. S., Klachkova O. A., \& Lukianova A.S. (2020). How does inflation influence income inequality in Russia? Voprosy Ekonomiki, 4, 54-66.

Kousar, R., Rais, S. I., Mansoor, A., Zaman, K., Shah, S. T. H., \& Ejaz, S. (2019). The impact of foreign remittances and financial development on poverty and income inequality in Pakistan: Evidence from ARDL-bounds testing approach. Journal of Asian Finance, Economics and Business, 6(1), 71-81. http:// doi.org/10.13106/jafeb.2019.vol6.no1.71

Law, C. H., \& Son, S. V. (2020). The Impact of Inflation on Income Inequality: The Role of Institutional Quality. Applied Economics Letters, 1-4. https://doi.org/10.1080/13504851.20 20.1717425

Lee, J. W., \& Lee, H. (2018). Human Capital and Income Inequality. Journal of the Asia Pacific Economy, 23(4), 554-583.

Le, N. H., Duy, L. V. Q., \& Ngoc, B. H. (2019). Effects of foreign direct investment and human capital on labour productivity: Evidence from Vietnam. Journal of Asian Finance, Economics and Business, 6(3), 123-130. https://doi.org/10.13106/ jafeb.2019.vol6.no3.123

Le, Q. H., \& Nguyen, B. N. (2020). The Impact of Credit on Income Inequality in Vietnam. Journal of Asian Finance, Economics, and Business, 7(5), 111-118. https://doi.org/10.13106/ jafeb.2020.vol7.no5.111

Lustig, N., Calva, L. F. L., \& Juarez, E. O. (2013). Declining Inequality in Latin America in the 2000s: The cases of Argentina, Brazil, and Mexico. Washington, DC: The World Bank

Olilingo, F. Z., \& Putra, A. H. P. K. (2020). How Indonesia Economics Works: Correlation Analysis of Macroeconomics in 2010-2019. Journal of Asian Finance, Economics and Business, 7(8), 117-130. https://doi.org/10.13106/jafeb.2020. vol7.no8.117

Sieron, A. (2017). Inflation and Income Inequality. Prague Economic Papers, 26(6), 633-645.

Siami-Namini, S. and Hudson, D. (2019), Inflation and income inequality in developed and developing countries. Journal of Economic Studies, 46(3), 611-632.

Salim, A., Rustam, A., Haeruddin, H., Asriati, A., \& Putra, A. H. P. K. (2020). Economic Strategy: Correlation between Macro and Microeconomics on Income Inequality in Indonesia. Journal of Asian Finance, Economics and Business, 7(8), 681-693. https:// doi.org/10.13106/jafeb.2020.vol7.no8.681

Todaro, M. P., \& Smith, S. C. (2012). Economic development. London, UK: Pearson Education. 